\title{
ANALYSIS OF DIFFERENT C:N RATIOS IN THE BIOFLOC SYSTEM ON THE GROWTH OF Pangasius hypophthalmus (Sauvage, 1878)
}

\author{
Akbar Maulana Sasry*1, Supono ${ }^{1}$, Wardiyanto ${ }^{1}$
}

\begin{abstract}
The development of catfish culture affects increasing waste in the waters. Aquaculture waste containing high nutrients has the potential to damage the cultivation environment. The Biofloc system in catfish farming can break down NH3 waste into flocks that can be consumed directly by fish. This study aims to analyze the growth and survival rate of catfish in biofloc systems with different $C: N$ ratios. The research design used was a completely randomized design (CRD) with four treatments and three replications. Siamese catfish seeds were maintained in an aquarium container size $40 \times 30 \times 30 \mathrm{~cm}$ for 40 days with treatment media $A$ (maintenance without biofloc), treatment $B C: N$ ratio 15 , treatment $C C: N$ ratio 20 , and treatment $D C: N$ ratio 25 . The results showed that the biofloc system with different $C: N$ ratios had significant effect on the weight growth, daily growth rate, and feed convertion ratio of catfish. The best treatment for growth and viability of catfish is $C: N$ ratio 25.
\end{abstract}

\section{Keywords: Biofloc, NH3, Pangasius hypophthalmus, $\mathrm{C}: \mathrm{N}$ ratio}

\section{Pendahuluan}

Ikan patin merupakan salah satu komoditas perikanan di Indonesia yang memiliki nilai ekonomis tinggi. Secara umum produksi ikan patin terus meningkat dengan pasar yang luas dan terbuka. Permintaan pasar yang terus meningkat setiap tahunnya, mengakibatkan berkembangnya jumlah produksi budidaya ikan patin. Berkembangnya proses budidaya ikan patin berpengaruh terhadap peningkatan limbah di perairan. Limbah akuakultur yang mengandung unsur hara yang tinggi berpotensi merusak lingkungan budidaya. De Schryver et al. (2008) dan Crab et al. (2007) menyatakan bahwa ikan hanya menyerap sekitar $25 \%$ pakan yang diberikan dan sisanya $75 \%$ menetap sebagai limbah di dalam air. Pemecah bahan organik oleh mikroba pada proses amonifikasi dapat menghasilkan amoniak $\left(\mathrm{NH}_{3}\right)$ dalam perairan. Manajemen budidaya yang berwawasan lingkungan sangat dibutuhkan untuk membantu permasalahan limbah akuakultur. Salah satu teknologi yang dapat mengatasi permasalahan limbah akuakultur yaitu bioflok (Riani et al., 2012).

Bioflok merupakan kumpulan organisme autotrof dan heterotrof serta limbah yang berintegrasi cukup baik di dalam air. Teknologi bioflok

\footnotetext{
* E-mail: maulana1429.ams@gmail.com

${ }^{1}$ Jurusan Perikanan dan Kelautan, Fakultas Pertanian, Universitas Lampung

Jl. Prof. S. Brodjonegoro No.1 Gedong Meneng Bandar Lampung, 35145
} 
dilakukan dengan menambahkan karbohidrat organik kedalam media pemeliharaan untuk meningkatkan rasio $\mathrm{C}: \mathrm{N}$ serta pertumbuhan bakteri heterotrof yang dapat mengasimilasi nitrogen anorganik menjadi biomass bakteri (Crab et al., 2007).

Teknologi bioflok merupakan teknologi penggunaan bakteri baik heterotrof maupun autotrof yang dapat menkonversi limbah organik secara intensif menjadi kumpulan mikroorganisme yang berbentuk flok, kemudian dapat dimanfaatkan oleh ikan sebagai sumber makanan (De Schryver dan Verstraete 2009; Avnimelech, 2012). Menurut De Schryver et al. (2008), pada kondisi rasio $\mathrm{C}: \mathrm{N}$ yang seimbang dalam media budidaya, bakteri heterotrof akan memanfaatkan $\mathrm{N}$, baik dalam bentuk organik maupun anorganik untuk pembentukan biomassa sehingga konsentrasi $\mathrm{N}$ dalam air menjadi berkurang. Perbandingan antara unsur karbon (C) dengan nitrogen (N) (rasio $\mathrm{C}: \mathrm{N}$ ), sangat penting diperlukan dalam sistem bioflok supaya bakteri dapat tumbuh dengan baik yang berpengaruh terhadap struktur pembentukan flok (Maulina, 2009). Nilai ideal perbandingan unsur karbon dengan nitrogen untuk bioflok adalah minimal 1:12 (Suryaningrum, 2012).

Penggunaan bioflok di perairan dapat memberi manfaat seperti sumber pakan tambahan untuk ikan (Rangka dan Gunarto, 2012), mengatasi limbah akuakultur (Riani et al., 2012), dan mengurangi nitrogen sehingga dapat memperbaiki kualitas air di perairan (Ekasari, 2009).

Untuk itu, perlu dikembangkan sistem budidaya yang efisien dalam mengatasi permasalahan kualitas air melalui rasio C:N yang berbeda pada sistem bioflok. Pada penelitian tersebut diharapkan dapat menentukan rasio $\mathrm{C}: \mathrm{N}$ yang tepat pada sistem bioflok untuk budidaya ikan patin. Penelitian ini bertujuan untuk menganalisis pertumbuhan dan tingkat kelangsungan hidup ikan patin pada sistem bioflok dengan rasio $\mathrm{C}: \mathrm{N}$ yang berbeda.

\section{Metode}

Penelitian ini dilaksanakan pada bulan Oktober sampai dengan November 2018 di Laboratorium Perikanan dan Kelautan, Program Studi Budidaya Perairan, Fakultas Pertanian, Universitas Lampung.

Penelitian ini dilaksanakan selama 40 hari menggunakan rancangan acak lengkap (RAL) dengan empat perlakuan dan tiga ulangan. Perlakuan A (kontrol) pemeliharaan ikan patin siam tanpa menggunakan bioflok, sedangkan perlakuan dengan bioflok didahului menambahkan $3 \mathrm{~g}$ pakan dan $1 \mathrm{ml}$ probiotik kedalam akuarium berisi 10 1 air tawar. Perlakuan B (C:N 15) menambahkan $0,6 \mathrm{~g}$ molase, perlakuan C (C:N 20) sebesar 1,02 g molase dan perlakuan D (C:N 25) sebesar 1,6 g molase.

Parameter yang diamati meliputi berat mutlak, laju pertumbuhan harian, SR, FCR, dan kualitas air. Sampling pertumbuhan, SR, dan FCR dilakukan setiap 10 hari sekali sedangkan sampling suhu dan pH dilakukan setiap hari, DO 4 hari sekali serta amonia dilakukan setiap 10 hari sekali.

Data pengamatan pertumbuhan, SR dan FCR diuji menggunakan 
analisis sidik ragam (ANOVA) dengan tingkat kepercayaan $95 \%$. Apabila data homogen dan hasil uji antar perlakuan berbeda nyata maka dilakukan uji lanjut Duncan.

\section{Hasil dan Pembahasan}

\section{Pertumbuhan}

Berdasarkan hasil penelitian pertumbuhan berat mutlak ikan patin tertinggi terdapat pada pemeliharaan ikan menggunakan sistem bioflok dengan rasio C:N 20 yaitu sebesar 6,26 g, diikuti rasio C:N 15 sebesar $6,25 \mathrm{~g}$, lalu pada perlakuan rasio $\mathrm{C}: \mathrm{N}$ 25 dengan nilai sebesar $6,13 \mathrm{~g}$, sedangkan nilai terendah pada perlakuan Kontrol tanpa bioflok sebesar 5,42 g.

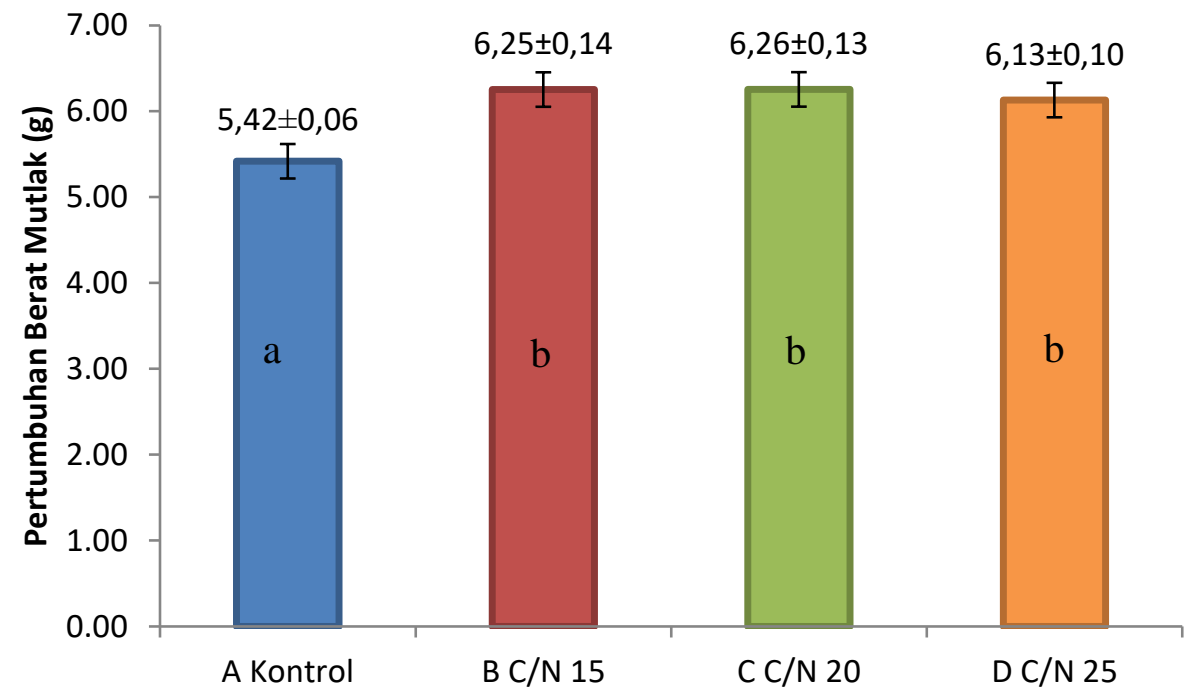

Keterangan: Huruf yang berbeda menunjukkan nilai yang berbeda nyata pada selang kepercayaan $95 \%$

Gambar 1. Pertumbuhan berat mutlak benih ikan patin

Pertumbuhan ikan pada setiap pemeliharaan mengalami perbedaan diduga karena perbedaan jumlah pakan yang diberikan dan dengan adanya bioflok yang membantu mengubah limbah hasil budidaya menjadi sumber energi cadangan bagi ikan sehingga pertumbuhan ikan menjadi lebih cepat, namun jika pakan yang diberikan kurang memenuhi kebutuhan nutrisi ikan maka kegiatan metabolisme ikan juga akan terganggu sehingga menghambat pertumbuhan ikan. Terbentuknya bioflok di perairan didukung oleh kondisi rasio $\mathrm{C}: \mathrm{N}$ dan bakteri pembentuk flok. Hal ini dikarenakan dalam bioflok mengandung polyhydroxybutyrate yang dapat meningkatkan pertumbuhan ikan. Polyhydroxybutyrate merupakan polimer yang paling dominan dan bermanfaat pada kegiatan budidaya perairan (Supono, 2014).

Berdasarkan hasil penelitian laju pertumbuhan harian pada pemeliharaan ikan patin tertinggi terdapat pada perlakuan bioflok dengan rasio $\mathrm{C}: \mathrm{N} 15$ sebesar 0,16 
g/hari, lalu diikuti rasio $\mathrm{C}: \mathrm{N} 20$ sebesar $0,16 \mathrm{~g} / \mathrm{hari}$ dan rasio C:N 25 sebesar $0,15 \mathrm{~g} /$ hari serta nilai terendah pada perlakuan tanpa bioflok sebesar $0,14 \mathrm{~g} /$ hari. Laju pertumbuhan yang lebih tinggi pada perlakuan bioflok diduga karena nilai nutrisi bioflok mampu meningkatkan pertambahan bobot pada ikan patin. Selain itu, menurut Huet (1971), jumlah dan komposisi serta kelengkapan asam amino yang terdapat dalam pakan juga dapat mempengaruhi laju partumbuhan ikan.

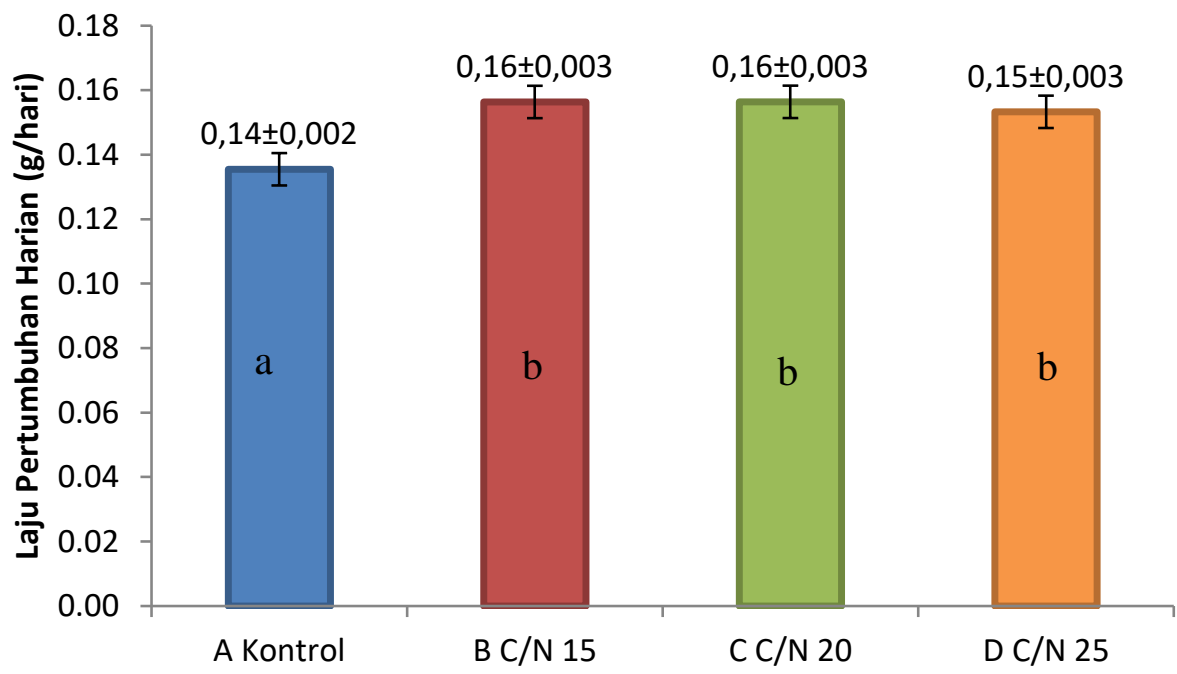

Keterangan: Huruf yang berbeda menunjukkan nilai yang berbeda nyata pada selang kepercayaan $95 \%$

Gambar 2. Laju pertumbuhan harian benih ikan patin

Laju pertumbuhan ikan dipengaruhi oleh jumlah nutrisi yang masuk ke dalam tubuh ikan. Jika nutrisi yang diberikan mampu mencukupi kebutuhan primer ikan maka pertumbuhan akan meningkat. Dalam penelitian digunakan pakan komersil dengan kualitas yang baik. Kandungan nutrisi pakan yaitu protein $39 \%$, lemak 5\%, serat kasar $6 \%$, abu $16 \%$ dan kadar air $10 \%$. Nilai nutrisi tersebut mampu memberikan laju pertumbuhan yang baik bagi ikan patin. Hal ini terlihat dari grafik sampling pertumbuhan ikan, dimana semua perlakuan mengalami grafik yang meningkat. Namun terdapat perbedaan nilai, dimana perlakuan bioflok lebih tinggi dibandingkan tanpa bioflok.Pada perlakuan bioflok nilai pertumbuhan yang dihasilkan lebih tinggi. Hal ini berarti dalam bioflok terkandung nilai gizi tambahan yang mampu memberikan nutrisi tambahan bagi ikan. Menurut Aiyushirota (2009) bahwa dalam bioflok terkandung karbohidrat sebesar $65 \%$, lemak $10 \%$ dan protein $32-62 \%$.

Menurut Crab et al. (2012) bioflok dapat memberikan nutrisi penting untuk meningkatkan kinerja pertumbuhan. Hal ini terjadi karena ikan mampu meman-faatkan kandungan protein dalam flok. Protein merupakan sumber energi utama bagi ikan sehingga tingginya 
kandungan protein dalam pakan dapat mempenga-ruhi pertumbuhan ikan.

\section{Kelangsungan Hidup}

Berdasarkan hasil penelitian kelangsungan hidup menunjukkan pada pemeliharaan ikan patin dengan perlakuan bioflok $\mathrm{C} / \mathrm{N} 15$ dan 25 dengan nilai sebesar 93\%, C/N 20 dengan nilai sebesar $87 \%$, sedangkan pada perlakuan tanpa bioflok atau perlakuan kontrol tingkat kelangsungan hidup terendah dengan nilai sebesar $80 \%$.

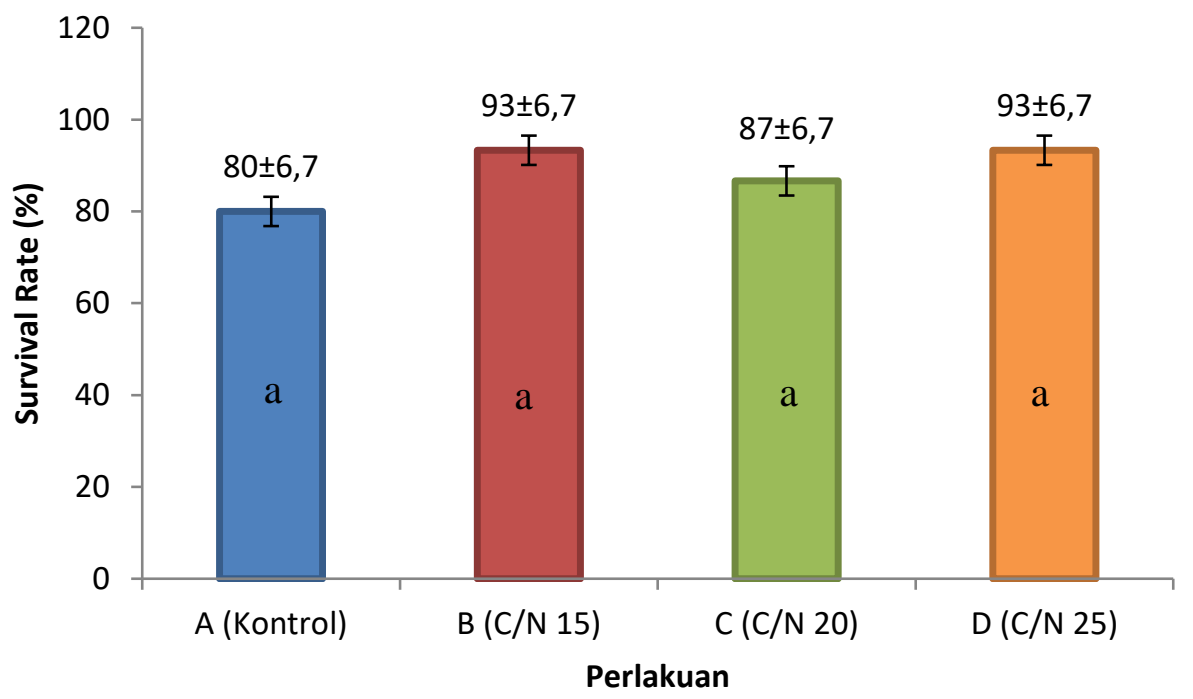

Keterangan: Huruf yang berbeda menunjukkan nilai yang berbeda nyata pada selang kepercayaan $95 \%$

\section{Gambar 3. Survival rate}

Hasil uji statistik menggunakan analisis uji Anova dengan tingkat kepercayaan $95 \%$ menunjukkan bahwa pemeliharaan ikan patin menggunakan bioflok tidak memberikan pengaruh yang nyata terhadap kelangsungan hidup. Faktor yang mempengaruhi kelangsungan hidup ikan dikelompokkan ke dalam dua golongan yaitu internal dan eksternal. Faktor internal berasal dari proses perkembangan biologi ikan dan faktor eksternal meliputi penyakit, hama, kualitas air, cuaca, dan pakan. Kematian ikan biasanya diakibatkan oleh persaingan antar ikan, lingkungan pemeliharaan tidak cocok, atau serangan hama dan penyakit. Mengetahui kematian ikan merupakan awal untuk mengetahui angka kelangsungan hidup ikan (Kordi, 2005).

Menurut Michaud et al.(2006), bakteri bioflok juga dapat mengakumulasi Polyhydroxybutyrate (PHB) yang diduga berperan dalam pengontrolan bakteri patogen pada sistem akuakultur. Adanya kandungan PHB pada bioflok yang menjadi pakan ikan pada perlakuan bioflok dianggap dapat meningkatkan sistem kekebalan tubuh sehingga ikan lebih tahan terhadap serangan patogen selama pemeliharaan.

Selama masa pemeliharaan ikan patin mengalami mortalitas pada hari ke-24 sampai dengan akhir pemeliharaan pada hari ke-40. 
Tingkat kelangsungan hidup ikan banyak dipengaruhi oleh faktor eksternal, seperti perubahan lingkungan dan penanganan ikan uji. Penanganan yang salah dapat menyebabkan ikan stress, sehingga kondisi kesehatan ikan menurun dan dapat menyebabkan kematian (Widiyati dan Praseno, 2002).

\section{Feed Convertion Ratio}

Berdasarkan hasil penelitian FCR ikan patin pada media perlakuan rasio C:N 15 sebesar 1,06 sedangkan pada perlakuan C:N 25 sebesar 1,05 dan $\mathrm{C}: \mathrm{N}$ rasio 20 sebesar 1,11 lalu nilai FCR terbesar yaitu pada perlakuan kontrol dengan nilai sebesar 1,16. Hal ini menunjukkan pemanfaatan pakan buatan oleh ikan patin selama masa pemeliharaan yang ditunjukkan oleh data efisiensi pakan dan konversi pakan memperlihatkan bahwa efisiensi pemanfaatan pakan pada perlakuan bioflok lebih baik dibandingkan tanpa bioflok atau perlakuan kontrol.

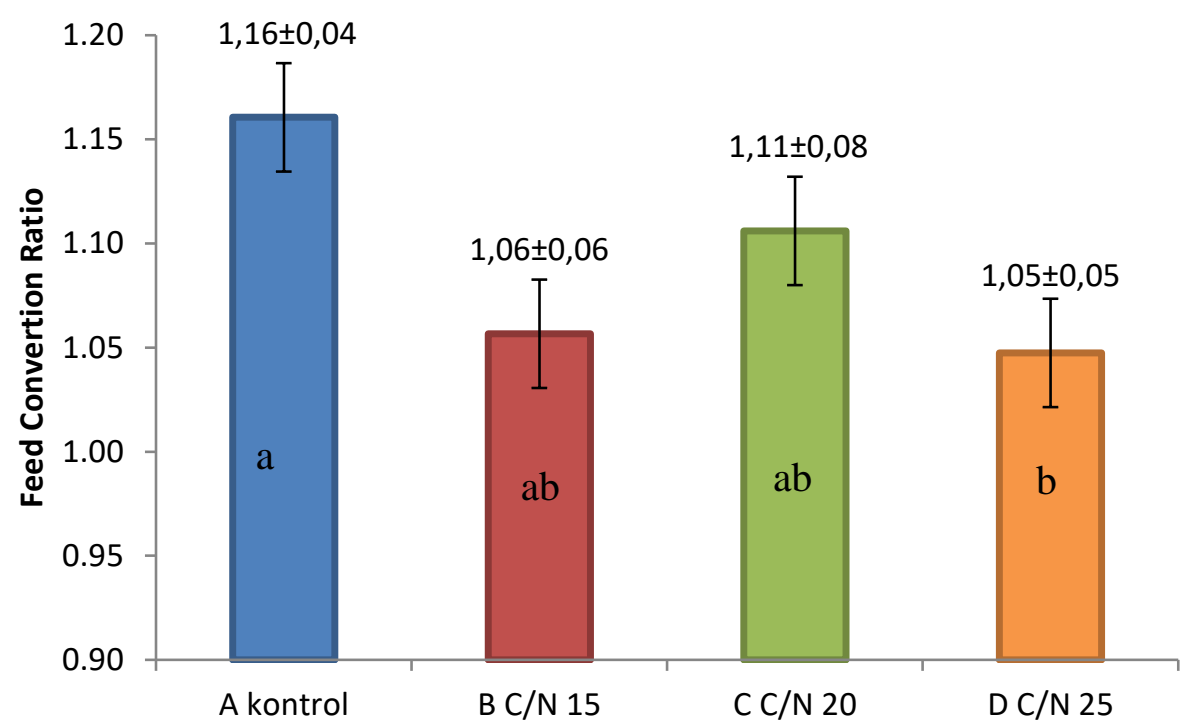

Keterangan: Huruf yang berbeda menunjukkan nilai yang berbeda nyata pada selang kepercayaan $95 \%$

Gambar 3. Feed convertion ratio

Pemeliharaan ikan tanpa bioflok hanya bergantung pada pemberian pakan komersil dimana sisa pakan dan hasil metabolisme tubuh ikan akan mengendap di dasar perairan dan akan bersifat toksik bagi ikan itu sendiri sehingga berpengaruh pada pertumbuhan dan kelangsungan hidup ikan. Sedangkan pada sistem bioflok menghasilkan FCR yang lebih rendah namun sebaliknya dengan pertumbuhan mutlak dan laju pertumbuhan harian ikan memiliki tingkat pertumbuhan tinggi serta tingkat kelulushidupan tinggi. Hal ini diduga karena jumlah pakan diberikan sesuai dengan kebutuhan nutrisi ikan karena dalam bioflok terdapat senyawa polyhydroxybutyrate yang memiliki fungsi sebagai cadangan energi pada tubuh ikan. Senyawa polyhydroxybutyrate inilah yang dimanfaatkan sebagai energi 
pengganti dalam proses metabolisme tubuh ikan, sintesis jaringan dan perbaikan tubuh sel, sehingga protein pakan yang terserap akan dimanfaatkan untuk partumbuhan selain itu bioflok juga berfungsi sebagai pengubah limbah anorganik hasil budidaya menjadi pakan alami tambahan ikan yang kaya kandungan protein sehingga pertumbuhan ikan dapat berjalan dengan baik.

\section{Kualitas Air}

Hasil penelitian menunjukkan bahwa nilai Suhu, DO, $\mathrm{pH}$, dan kandungan amoniak dalam media pemeliharaan masih dalam kondisi optimum dengan kisaran nilai Suhu $25-31{ }^{\circ} \mathrm{C}$, DO pada kisaran $3-4,5$ $\mathrm{mg} / \mathrm{l}, \mathrm{pH}$ pada kisaran $6,5-8,5$, dan nilai amoniak pada semua perlakuan $<0,1 \mathrm{mg} / \mathrm{l}$. Tabel 1 menunjukkan parameter kualitas air (Suhu, DO, pH, dan amoniak) selama penelitian.

Tabel 1. Kualitas air selama penelitian

\begin{tabular}{|c|c|c|c|c|c|c|}
\hline \multirow{2}{*}{ Parameter } & \multicolumn{5}{|c|}{ Perlakuan } & \multirow{2}{*}{$\begin{array}{l}\text { Kisaran } \\
\text { Optimal }\end{array}$} \\
\hline & & $\mathbf{A}$ & B & $\mathbf{C}$ & D & \\
\hline \multirow{3}{*}{ Suhu $\left({ }^{\circ} \mathrm{C}\right)$} & Pagi & $25-27$ & $25-26$ & $25-27$ & $25-27$ & \multirow{3}{*}{$28-32^{(a)}$} \\
\hline & Siang & $29-30$ & $29-30$ & $29-30$ & $29-30$ & \\
\hline & Sore & $28-29$ & $28-29$ & $28-29$ & $28-29$ & \\
\hline \multirow{3}{*}{ DO (mg/l) } & Pagi & $4,13-5,06$ & $4,27-5,32$ & $4,09-5,15$ & $4,11-5,19$ & \multirow{3}{*}{$3-6^{(a)}$} \\
\hline & Siang & $3,25-3,99$ & $3,52-4,11$ & $3,35-3,96$ & $3,23-3,98$ & \\
\hline & Sore & $3,51-4,03$ & $3,80-4,19$ & $3,62-4,04$ & $3,74-4,14$ & \\
\hline \multirow{3}{*}{$\mathrm{pH}$} & Pagi & $7,17-7,38$ & $6,93-7,41$ & $6,96-7,28$ & $7,16-7,36$ & \multirow{3}{*}{$6-8.5^{(a)}$} \\
\hline & Siang & $6,85-7,58$ & $7,10-7,62$ & $7,11-7,76$ & $7,50-7,82$ & \\
\hline & Sore & $7,39-7,73$ & $7,41-7,80$ & $7,28-7,50$ & $7,32-7,71$ & \\
\hline \multirow{3}{*}{$\begin{array}{c}\text { Amoniak } \\
(\mathrm{mg} / \mathrm{l})\end{array}$} & Awal & 0,049 & 0,041 & 0,041 & 0,043 & \multirow{3}{*}{$<0,1^{(\mathrm{b})}$} \\
\hline & Tengah & 0,085 & 0,066 & 0,074 & 0,074 & \\
\hline & Akhir & 0,096 & 0,065 & 0,074 & 0,072 & \\
\hline
\end{tabular}

Keterangan : (a) Sularto et al. (2007)

(b) Djariah (2001)

\section{Kesimpulan dan Saran}

Penggunaan $\mathrm{C} / \mathrm{N}$ rasio yang berbeda dalam sistem bioflok tidak membe-rikan pengaruh nyata terhadap pertumbuhan dan kelangsungan hidup ikan patin, namun berpengaruh nyata terhadap perlakuan tanpa bioflok. Penggunaan rasio C:N 25 disarankan untuk diaplikasikan pada budidaya ikan patin untuk mencapai nilai optimum pertumbuhan dan kelangsungan hidup ikan patin.

\section{Daftar Pustaka}

Afrianto, E \& Liviawaty, E. 2005. Pakan Ikan. Kanisius, Yogyakarta. $148 \mathrm{hlm}$.

Aiyushirota, I. 2009. Konsep Budidaya Udang Sistem Bakteri Heterotrof Dengan Bioflok. Aiyushirotabiota, Indonesia.

Aljabbar, I. 2005. Penggunaan Tepung Bungkil Kedelai Sebagai Pengganti Tepung Ikan Dalam Pakan Juvenil Kerapu Bebek. Skripsi. Fakultas Perikanan dan Ilmu Kelautan, IPB, Bogor. 41 hlm.

Amri \& Khairuman. 2008. Syarat Hidup dan Kebiasaan Hidup 
Ikan Patin. Agromedia Pustaka, Jakarta.

Asyari, A., Arifin, Z., \& Utomo, A. D. 2017. Pembesaran Ikan Patin (Pangasius pangasius HB) Dalam Sangkar di Sungai Musi Sumatera Selatan. Jurnal Penelitian Perikanan Indonesia, 3(2): 83-90.

Avnimelech, Y. 1999. C/N Ratio As a Control Element in Aquaculture Systems. Aquaculture, 176: 227-235.

Avnimelech, Y., dan Ritvo, G. 2003. Shrimp and fish pond soils: processes and management. Aquaculture, 220: 549-567.

Brune, D. E., G. Schwartz, A. G. Eversole, J. A. Collier \& T. E. Schwedler. 2003. Intensification of Pond Aquaculture and High Rate Photosythetic Sytems. Aquaculture Engineering, 8: 65-86.

Crab, R., Avnimelech, Y., Defoird, T., Bossier, P., dan Verstrate, W. 2007. Nitrogen removal Techniques in Aquaculture for Sustainable Production. Aquaculture, 270: 1-14.

Crab, R., Defoirdt, T., Bossier, P., dan Verstrate, W. 2012. Biofloc Technology in Aquaculture: Beneficial Effects and Future Challenges. Aquaculture, 356: 351-356.

De Schryver, P., Crab, R., Defoird, T., Boon, N., \& Verstraete, W., 2008. The Basics of Bio-Flocs Technology: The Added Value for Aquaculture. Aquaculture, 277: 125-137.

Djariah, A.S. 2001. Budidaya Ikan Patin. Kanisius, Yogyakarta. 87 hlm.
Ebeling, J.M., Timmons, M.B., \& Bisogni, J.J. 2006. Engineering analysis of the stoichiometry of photoautotrophic, autotrophic, and heterotrophic removal of ammonia-nitrogen in aquaculture systems. Aquaculture, 257(1-4): 346358.

Effendi. 2003. Biologi Perikanan. Yayasan Pustaka Nusantara, Yogyakarta. $157 \mathrm{hlm}$.

Effendie, M.I. 1997. Biologi Perikanan. Yayasan Pustaka Nusantara, Yogyakarta. 132 hlm.

Ekasari, J. 2009. Teknologi Bioflok: Teori dan Aplikasi dalam Perikanan Budidaya Sistem Intensif. Fakultas Perikanan dan Ilmu Kelautan Institut Pertanian Bogor. Jurnal Akuakultur Indonesia, 8(2): 117-126.

Fujaya, Y. 2004. Fisiologi Ikan. Dasar Pengembangan Teknik Perikanan. PT. Rineka Cipta, Jakarta.

Ghufran. 2005. Budidaya Ikan Patin, Biologi, Pembenihan dan Pembesaran. Yayasan Pustaka Nusantara, Yogyakarta.

Ghufran. 2010. Panduan Lengkap Memelihara Ikan Air Tawar Di Kolam Terpal. Ed. 1. Lily Publisher, Yogyakarta. Hal 815.

Gunarto, Muliani, \& Mansyur, A. 2010. Pengaruh aplikasi sumber $\mathrm{C}$ karbohidrat (tepung tapioka) dan fermentasi probiotik pada budidaya udang windu (Penaeus monodon) pola intensif di tambak. Jurnal Riset Akuakultur, 5(3): 393-409 
Gusrina. 2008. Budidaya Ikan. Departemen Pendidikan Nasional, Jakarta.

Gross, A., Boyd, C.E., \& Wood, C.W. 2000. Nitrogen Transformation and Balance In Channel Catfish Ponds. Aquaculture Engineering, 24: 1-14.

Hargreaves, J.A., 1989. Nitrogen Biogeochemistry Aquaculture Ponds. Aquaculture, 166: 181-212.

Huet, M. 1971. Textbook of fish culture: breeding and cultivation of fish. Fishing News, London. 436 hal.

Khairuman. 2002. Budidaya Patin Super. Agromedia Pustaka, Jakarta.

Khairuman \& Dodi, S. 2002. Budidaya Ikan Patin Secara Intensif. Agromedia Pustaka, Jakarta.

Khrishna, C. \& Van Loosdrecht, M.C.M. 1999. Effect of temperature on storage polymers and settleability of activated sludge. Water Res. 33(10): 2374-2382

Kordi, M.G.H. 2005. Budidaya Ikan Patin: Biologi, Pembenihan dan. Pembesaran. Yayasan Pustaka Nusatama, Yogyakarta.

Masyamsir. 2001. Membuat Pakan Ikan Buatan. Departemen Pendidikan Nasional, Jakarta.

Maulina, N. 2009. Aplikasi Teknologi Bioflok dalam Budidaya Udang Putih (Litopenaeus vannamei boobe). ITB, Bandung.

Michaud, L., Blancheton, J., Bruni, V., \& Piedrahita, R. 2006. Effect of Particulate Organik Carbon on Heterotrophic Bacterial Populations and
Nitrification Efficiency in Biological Filters. Aquaculture Engineering, 34(3): 224-233.

Millamena, O.M., Relicado, M.C., \& Felicitas, P.P. 2002. Nutrition in Tropical Aquaculture. Southeast Asian Fisheries Development Center. Tigbauan, Iloilo, Philippines.

Mudjiman, A. 2000. Makanan Ikan. Penebar Swadaya, Jakarta.

Rangka, A.N. \& Gunarto, 2012. Pengaruh Penumbuhan Bioflok Pada Budidaya Udang Vaname Pola Intensif di Tambak. Jurnal Ilmiah Perikanan dan Kelautan, 4(2): 141-149.

Riani, H., Rostika, R., \& Lili, W. 2012. Efek Pengurangan Pakan Terhadap Pertumbuhan Udang Vaname (Litopenaeus vannamei) PL-21 yang diberi bioflok. Jurnal Perikanan Kelautan, 3(3): 207-211.

Sticney, R.R. 2005. Aquaculture: An Introductory text. CABI Publishing. USA. $256 \mathrm{hlm}$.

Sudjana. 2005. Metode Statistika. Penerbit Tarsito, Bandung.

Suguna, P., Binuramesh, C., Abirami, P., Saranya, V., Poornima, K., Rajeswari, P., \& Shenbagarathai, R. 2013. Imunostimulation by polyhydroxy-butyratehydroxyvalerate from Bacillus thuringiensis in Oreochromis mossambicus. Fish and Shellfish Immunology, 36(1): 90-97.

Sularto, Hafsaridewi, R., \& Tahapari, E. 2007. Petunjuk Teknis Pembenihan Ikan Pasupati. LRPT-BPAT Sukamandi, Jawa Barat. 7 hlm. 
Suryaningrum, M.F. 2012. Aplikasi

Teknologi Bioflok pada

Pemeliharaan Benih Ikan Nila

(Oreochromis niloticus). Tesis.

Universitas Terbuka, Jakarta.

Susantyo, E. 2011. The Effect of Palm

Oil, Peanut Oil and Margarine

on Serum Lipoprotein and

Aterosklerossis in Rats. Jurnal

Gizi Indonesia, 2(1): 19-29.

Susanto, H. 2009. Pembenihan dan Pembesaran Patin. Penebar Swadaya, Jakarta.

Supono. 2014. Manajemen Kualitas Air Untuk budidaya Perairan. Buku Ajar. Universitas Lampung, Bandar Lampung. $105 \mathrm{hlm}$.

Widiyati, A. \& Praseno, O. 2002. Peranan Vitamin C dalam Mencegah dan Mengurangi Stres pada Benih Ikan. Warta Penelitian Perikanan Indonesia, 8(1): 853-894. 